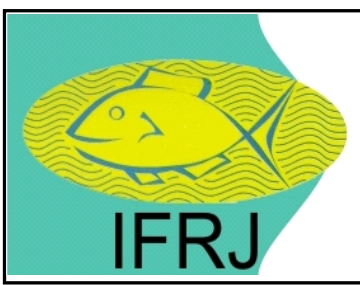

Available online at: http://ejournal-balitbang.kkp.go.id/index.php/ifrj

e-mail:ifrj.puslitbangkan@gmail.com

INDONESIANFISHERIES RESEARCHJOURNAL

Volume 23 Nomor 2 December 2017

e-ISSN: 2502-6569

Accreditation Number: 704/AU3/P2MI-LIPI/10/2015

\title{
FACTORS INFLUENCING THE PERFORMANCE OF TRAWL OPERATION IN THE WATERS AREA OF TARAKAN
}

\author{
Asep Priatna ${ }^{* 1}$ and Suprapto ${ }^{1}$ \\ ${ }^{1}$ Research Institute for Marine Fisheries \\ Jl, Raya Bogor No.507, Nanggewer Mekar, Cibinong, Bogor, Jawa Barat 16912, Indonesia \\ Received; September 07-2017 Received in revised from December 07-2017; Accepted January 05-2018
}

\begin{abstract}
Any fish on swept area of bottom trawl could not be caught due to some technical factors during towing. However, it could be estimated by integrated of bottom trawl and acoustic survey. This paper describes the determination of some factors that affect the performance of trawl net during the bottom trawl survey in the waters of Tarakan. Surveys were carried out in May, August, and November 2012. A total of 57 stations of simultaneously acoustic-trawl were completed. Data collected from each station include catch composition, and variables of trawling operation (i.e. bottom depth, warp length, trawl door opening, towing speed, towing duration, and acoustic fish density). Principal component analysis was applied to identify variables might impact of trawling performance (i.e. fish density at the waters area, towing speed, towing duration, warp length, horizontal opening of trawl door, density of non-demersal at cod end, and bottom depth). Both towing speed and towing duration were not major component for trawl operation. According to test of significance for four variables (i.e. bottom depth, warp length, horizontal opening, biota nondemersal at cod end) which affected to fish density at waters area, that both of variable (i.e. warp length and bottom depth) were significant as the principal components for the performance of bottom trawl.
\end{abstract}

\section{Keywords: Bottom trawl; acoustic; principal components; Tarakan}

\section{INTRODUCTION}

The bottom trawl has long been used as a fishing gear for demersal fish stock assessment. There are two major sources of error in estimates of fish abundance derived from trawl surveys (Grosslein \& Laurec, 1982). First one is measurement error, as a systematic error or bias which arises because trawl does not catch every fish on swept area, the trawl efficiency or "catchability" is less than 1 . The second one is sampling error related to variability of spatial distribution. Therefore, it is important to know the value and causes of both types of error (i.e. bias and variance), to maximize efficiency of design of trawl survey, and to avoid the errors if fish biomass is changed.

The catchability of a bottom trawl could be affected by several factors, i.e. fish behavior such as horizontal and vertical distribution, fish avoidance to trawl and vessel, and bottom trawl selectivity as a fishing gear (Walsh, 1996). Swept area method was conducted to estimate the abundance of demersal fish by bottom trawl operated simultaneously with acoustic survey in Tarakan waters. According to ratio between demersal fish density from acoustic surveys and swept area method, trawl density was lower than acoustic density (Priatna et al., 2014). Bottom trawl not caught all fish available on the swept area during towing.

The catchability coefficient of small bottom trawl based and operated in Tarakan was about 0.3 (Priatna et al., 2014). It means that only $30 \%$ of all fish on swept area were caught and about $70 \%$ of fish were escape. This gaves an estimation the number of escape fish (could not caught) is twice than those caught by trawlers.

In addition, bottom trawl could not catch every fish available on the swept area, due to fish reactions to avoid or escape from trawl net, and the presence of trawl pathway area. The horizontal and vertical distributions are natural behavior of fish in trying to avoid the arrival of vessel and trawl net. Those two variables seem to be difficult to measure and cause unestimated fish density in the pathway areas. 
Technically, the pathway area is the space where is not swept by trawl. Therefore, fish in the pathway areas could not be caught during towing. Fish abundance at the pathway areas due to technical factors during trawl operation could not be estimated. In addition fish are not caught during trawling operation due to technical factors determined by catchability of trawl net.

Integration both of acoustic and trawl surveys can estimate fish density on the pathway area. In addition, through technical aspects measurement of trawling including bottom depth, warp length, opening of trawl mouth, towing speed, towing duration, current flow, and wind speed technical factors that cause the pathway area of trawl surveys can be identified. The aim of this study is to determine the technical factors that affect the performance trawl net in the pathway area during bottom trawl survey in Tarakan waters.

\section{MATERIALS AND METHODS}

The combining use of bottom trawl and acoustic survey to estimate demersal fish density was carried out in May, August, and November 2012 in Tarakan waters (RIMF, 2012). The integrated stations of acoustic-trawl have been done at Stasiun No. 21, 20, and 21 (Figure 1). Two aspects including the catch composition (demersal fish from trawling and acoustic fish density) and technical aspects of trawling (i.e. depth, warp length, trawl door opening, speed and towing duration) were observed during surveys.

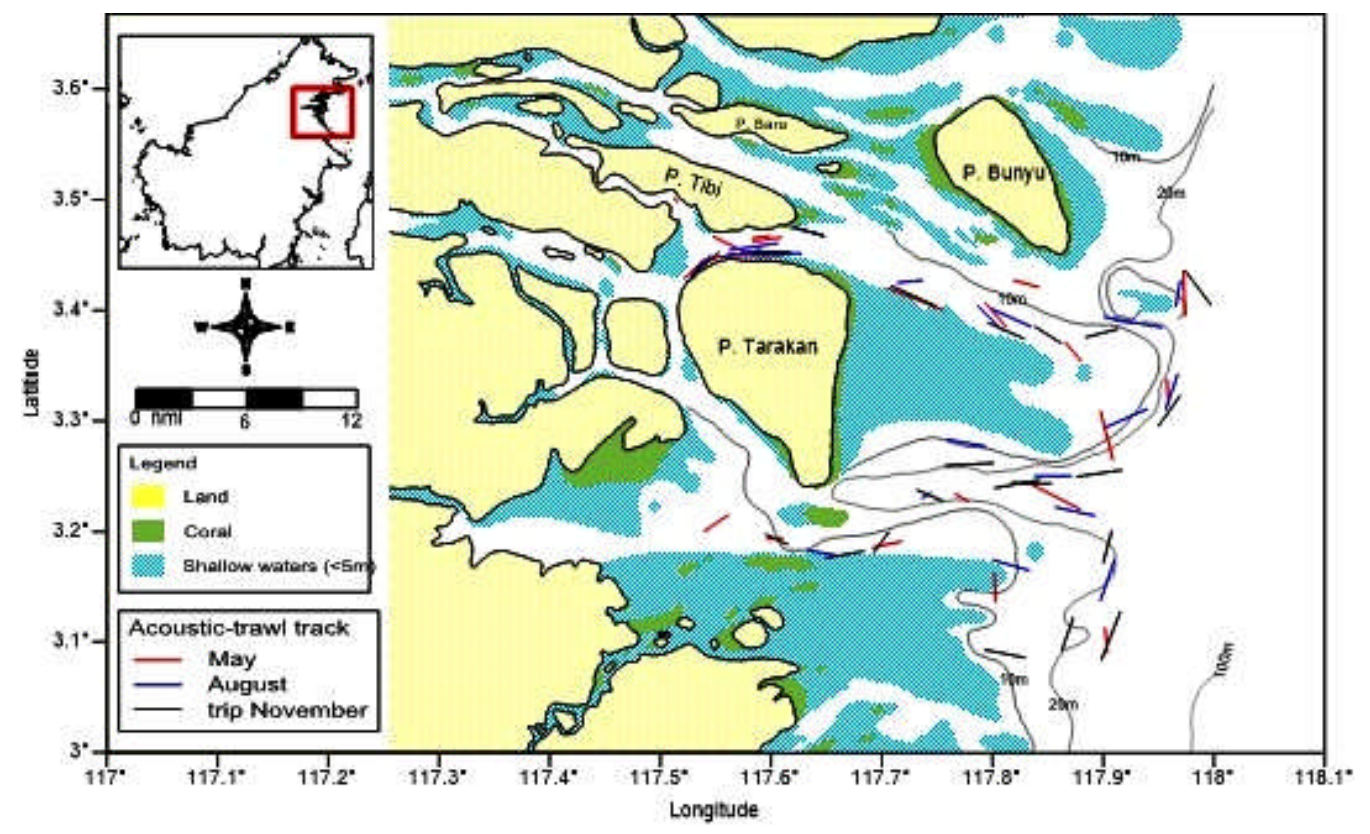

Figure 1. Trawl-acoustic sampling positions in May, August and November 2012 (Priatna et al., 2014).

\section{Data Collecting}

A local small trawler 20 GT equipped with bottom trawl $26 \mathrm{~m}$ head-rope was used during survey. Towing duration was about 1 hour with towing speed of 3 knots for each trawling operations. Acoustic data including fish density, bottom depth, were collected by echosounder SIMRAD EY60-120 KHz, equipped with GPS to determine positions of boat and fish.

\section{Data Analysis}

\section{Swept Volume of Bottom Trawl}

Horizontal opening $\left(\mathrm{H}_{\mathrm{o}}\right)$ value of trawl door is adopted from Tampubolon \& Monintja (1995). Swept area $\operatorname{trawl}(A)$ is then calculated by using the formula described by Pauly et al. (1996):
$A=H_{0} \times V \times t$.

where;

$\mathrm{V}$ = towing speed $(\mathrm{m} / \mathrm{s})$

$\mathrm{t}=$ towing duration (s).

The estimate vertical opening of trawl door $(\mathrm{Vo})$ is following FAO (1990):

$\mathrm{Vo}=2 \times \mathbf{N} \times$ a $\times 0,05$

where,

$\mathrm{N}=$ number of mesh at trawl body

$\mathrm{a}=$ mesh size at trawl body.

The estimation swept volume (Vs) of trawl is then calculated: 
$\mathrm{Vs}=\mathrm{A} \times \mathrm{Vo}$

where:

$A=$ swept area $\left(\mathrm{m}^{2}\right)$

$\mathrm{Vo}=$ vertical opening of trawl door $(\mathrm{m})$.

\section{Acoustic Data}

During towing, position of trawl net far behind the boat. It various distances between trawl net and boat every trawling operation, depending on bottom depth. Therefore, echograms were analyzed in accordance with towing track range when trawl net hit until left the bottom. Horizontal distance between boat and trawl net was estimated geometrically by warp length and bottom depth (Wallace \& West, 2006) as follow:

$\mathrm{D}=\left(L w^{2}-y^{2}\right)^{1 / 2}$

where;

$\mathrm{Lw}=$ length of $\operatorname{warp}(\mathrm{m})$

$y=\operatorname{depth}(m)$.

Echogram is scrutinized by Ecoview software, elementary sampling distance unit (ESDU) was every $100 \mathrm{~m}$ (Mello et al., 2009). According equation from Ona \& Mitson (1996) Priatna et al. (2014) describe that acoustic dead zone (ADZ) or back-step zone (BSZ) was about $25 \mathrm{~cm}$. Determination of BSZ to minimize echo integration from the bottom. BSZ limitation should not be crossed the bottom, to obtained accurate echo integration. Bias of demersal fish echo integration, due to backscattering from bottom echo (Von Szalay et al., 2007).

Furthermore, integration of acoustic data carried on the layer from BSZ $(25 \mathrm{~cm})$ to $2.5 \mathrm{~m}$ from bottom, referred to vertical opening of head-rope deriver equation 2. According to the synchronization between acoustic density and vertical opening of trawl mouth, both acoustic density (DA) and trawl density (DT) can be compared.

Acoustic density was calculated refer to MacLennan \& Simmonds, (2005):

$\mathrm{TS}_{\mathrm{i}}=10 \log \mathrm{o}_{\mathrm{bsi}}$

$\tilde{\mathbf{n}} \mathbf{A}=\mathrm{NASC} / \mathbf{o}_{\mathrm{b}}$

$\tilde{n} V=\tilde{n} A \times r$

where,

$\mathrm{TS}_{\mathrm{i}}=$ target strength of fish $-\mathrm{i} ; \mathrm{o}_{\mathrm{bsi}}=$ backscattering crossection fish-i; NASC=Nautical area scattering coefficient $\left(m^{2} \times n m^{-2}\right) ; r=$ thickness $(m) ; \tilde{n} A=a r e a$

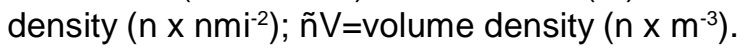

\section{Fish Density on Trawl Dead Zone}

Test of both treatments (i.e. differences and ratio) between DA and DT may determine fish density on the pathway area $\left(D_{T D Z}\right)$. The independent t-test carried to averages of differences $D_{T D Z}$ each combination sampling period. As well as to determine $D_{T D Z}$ was independent population from three field surveys. Hypothesis- 1 could be derivedr $\mathrm{H} 0=$ both sampling period have equivalent of variance; $\mathrm{H} 1=$ both of sampling period not have equivalent of variance. Hypothesis 2 is $\mathrm{H} 0=$ both sampling period have same mean density; $\mathrm{H} 1=$ both sampling periods not have same mean density.

\section{Principal Component of Trawl Survey}

Principal component analysis (PCA) was used to set variables of fish density in the pathway area. The variables were measured such as fish density in the pathway area $|\mathrm{C}|$, towing speed $(\mathrm{X} 1)$, towing duration (X2), warp length (X3), horizontal opening of trawl door (X4), density of biota non demersal at codend (X5), and bottom depth (X6). These were used to set on a grouping to new variable according to closeness of relationship between dimensions of forming factors.

According to PCA, data presentation was expressed in matrix $57 \times 7$ (57 observations and 7 variables). Then, it was reduced into smaller matrix and contains 57 measurements on $\mathrm{k}$ principal components. Dimension of matrix will be $57 \times \mathrm{k}$ (57 observations and k factors). Regarding data structure, results of analysis factor with component of variance (eigenvalue) should be more than 1 (Hair et al., 1998). The threshold of total variance that was explained by common factor was $\geq 60 \%$. If correlation between factors formed and variables have had absolute value $\geq 0.5$, or could be tested by t-test and it significant, that variable $X_{i}$ was valid to serve as a member of relevant factor.

PCA is early step to define those variables which have real contribution of catch. Hypothesis-1 regarding significance of these variables, $\mathrm{H} 0=$ correlation between variables were not significant; $\mathrm{H} 1=$ at least there is a significant correlation between variables.

Furthermore, PCA would be formed factors. A new hypothesis obtained and used as an initial hypothesis in further analysis. The variables in new hypothesis, should be have not double collinearity between 
independent variables $(\mathrm{Xi})$ as input to build the regression analysis, t-test, F-test, or ANOVA between variables $|\mathrm{C}|, \mathrm{X}_{1}, \mathrm{X}_{2}, \mathrm{X}_{3}, \mathrm{X}_{4}, \mathrm{X}_{5}$, and $\mathrm{X}_{6}$. Finally, a new composition for principal components would be formed. Then, t-test used to measure the significance of variable of density on the pathway area $|\mathrm{C}|$ with hypothesis- 2 is $\mathrm{HO}=$ coefficient of variable-i not significant; $\mathrm{H} 1=$ coefficient of variable-i significant.

\section{RESULTS AND DISCUSSION Results}

\section{Fish Density on The pathway Area}

The identification by treatment of DA and DT was measured before independent T-test analysis according to differences of mean of $D_{T D Z}$ from each combination of survey period (Table 1). The mean of fish density for each treatment showed that DA was higher than DT. That every fish were available on swept area were not caught, presence the the pathway area during trawling operation.

The significant value obtained at ratio of mean $|\mathrm{C}|$ between trip on August and November, rejected $\mathrm{H} 0$. Value of $|\mathrm{C}|$ for both trips did not have same variance. T-test (2.46) was > t-table (2.04), rejecting $\mathrm{HO}$. Value of $|\mathrm{C}|$ for both trips did not have same average of fish density (Table 2). Therefore, $D_{T D Z}$ is differences between DA (corrected) and DT. The rejection hypothesis $\mathrm{H} 1$ when treatment (i.e. $\mathrm{C} 1$ vs $\mathrm{C} 2$ and $\mathrm{C} 1$ vs C3), indicated there were changes in characteristics of population that was hypoth.

Table 1. Fish density of demersal fish from acoustic surveys (DA) and trawl (DT) for each trip and treatment (differences and ratio).

\begin{tabular}{|c|c|c|c|c|c|c|c|c|}
\hline Trip & Month & Treatment & Code & $\begin{array}{c}\text { Sta } \\
\text { number }\end{array}$ & $\begin{array}{c}\text { mean } \\
\text { DA (log) }\end{array}$ & $\begin{array}{c}\text { mean DT } \\
(\log )\end{array}$ & $\begin{array}{c}\text { mean } \\
\text { treatment }\end{array}$ & $\begin{array}{c}\text { Std. } \\
\text { deviation }\end{array}$ \\
\hline & & Difference & & & & & & \\
\hline 1 & May & Acoustic-Trawl & $\mathrm{C} 1$ & 17 & 4.30 & 3.19 & 1.11 & 0.94 \\
\hline 2 & August & Acoustic-Trawl & $\mathrm{C} 2$ & 17 & 4.11 & 3.15 & 0.97 & 0.92 \\
\hline \multirow[t]{2}{*}{3} & November & Acoustic-Trawl & C3 & 16 & 4.72 & 3.42 & 1.29 & 0.76 \\
\hline & & Ratio & & & & & & \\
\hline 1 & May & Acoustic:Trawl & Y1 & 17 & 4.20 & 3.12 & 1.35 & 0.66 \\
\hline 2 & August & Acoustic:Trawl & Y2 & 17 & 4.48 & 3.33 & 1.35 & 0.67 \\
\hline 3 & November & Acoustic:Trawl & Y3 & 16 & 4.39 & 3.33 & 1.32 & 0.66 \\
\hline
\end{tabular}

Table 2. Test of T-student according differences of average $\mathrm{D}_{\mathrm{TDZ}}$ between two surveys

\begin{tabular}{ccccc}
\hline \multirow{2}{*}{ Treatment } & \multicolumn{4}{c}{ t-test with confidence interval $\mathbf{9 5 \%}\left(\mathbf{t}_{\mathbf{0}, 05 / 2}\right)$} \\
\cline { 2 - 5 } & $\mathbf{t}$ & $\mathbf{S i g}$ & $\mathbf{d f}$ & $\mathbf{t}$ \\
\hline C1 vs C2 & 0.30 & 0.77 & 27 & 2.05 \\
C1 vs C3 & -1.97 & 0.06 & 24 & 2.06 \\
C2 vs C3 & $\mathbf{- 2 . 4 6}$ & $\mathbf{0 . 0 2}$ & $\mathbf{3 1}$ & $\mathbf{2}$ \\
Y1 vs Y2 & 0.74 & 0.47 & 27 & 2.05 \\
Y1 vs Y3 & -1.10 & 0.28 & 28 & 2.05 \\
Y2 vs Y3 & -1.94 & 0.06 & 32 & 2.04 \\
\hline
\end{tabular}

\section{Principal Component of Survey Trawl}

The correlation matrix (Table 3) by PCA (Principal Component Analysis), showed relationship between variables of trawling from 57 stations acoustic-trawl during survey. It shows most coefficient correlation between variables involved trawl catch about $<0.5$.

Table 3. The correlation matrix between trawling variables

\begin{tabular}{lccccccc}
\hline Variables & $|\mathbf{C}|$ & Speed & Duration & Warp & Opening & Codend & Depth \\
\hline$|\mathrm{C}|$ & $\mathbf{1}$ & & & & & & \\
Speed & -0.09 & $\mathbf{1}$ & & & & & \\
Duration & 0.21 & -0.16 & $\mathbf{1}$ & & & & \\
Warp & -0.08 & 0.24 & -0.06 & $\mathbf{1}$ & & & \\
Opening & -0.22 & 0.11 & -0.04 & $\mathbf{0 . 3 6}$ & $\mathbf{1}$ & $\mathbf{1}$ & $\mathbf{1}$ \\
Codend & $\mathbf{0 . 5 7}$ & -0.04 & 0.20 & $\mathbf{- 0 . 4 1}$ & -0.06 & $\mathbf{1}$ \\
Depth & $-\mathbf{0 . 7 5}$ & 0.16 & -0.18 & $\mathbf{0 . 3 8}$ & 0.15 & $\mathbf{0 . 6 8}$ & \\
\hline
\end{tabular}

Values in bold are significant at $95 \%$ confidence interval 
Otherwise, by overall PCA identification, $\mathrm{KMO}$ value was about 0.57 and significant $(P<0.05)$. Therefore, parameters of trawling were worthy for component analysis. In some PCA analysis, the statistical value of Kaiser Meyer Olking (KMO) was $\geq 0.5$ and significant of Bartlett's test $(p<0.05)$.
Number of common factor was formed as many as number of variables constituent (i.e. 7 common factors). According to components with eigenvalue $\geq$ 1 , formed 3 common factors (i.e. F1, F2, F3) with percentage of cumulative variance about $70.98 \%$ (Table 4).

Table 4. Eigenvalue and percentage of variances for each component

\begin{tabular}{lrrrrrr}
\hline \multirow{2}{*}{ Eigenvalue } & \multicolumn{7}{c}{ Component } \\
\cline { 2 - 8 } & \multicolumn{1}{r}{ F1 } & \multicolumn{1}{c}{ F2 } & \multicolumn{1}{c}{ F3 } & \multicolumn{1}{c}{ F4 } & \multicolumn{1}{c}{ F5 } & F6 \\
\hline Value & 2.70 & 1.23 & 1.03 & 0.83 & 0.75 & 0.30 \\
\% Varians & 38.61 & 17.64 & 14.73 & 11.86 & 10.67 & 4.24 \\
\% Cumulative & 38.61 & 56.25 & 70.98 & 82.84 & 93.50 & 97.74 \\
\hline
\end{tabular}

The value of component factor is the correlation between formed factors and variables. Variables with absolute value $\geq 0.5$ on one of component factor are member of formed factors and vice versa. Towing speed and warp length have two absolute values $(\geq 0.5)$ of components factors (Table 5). It should be orthogonal rotation to components factor, so each variable has only one value $(\geq 0.5)$ of component factor. Once rotated, two parameters are not members of common factor (i.e. towing speed and towing duration), which have absolute value $(<0.5)$ of component factor ( F1 and F2). Therefore, these components should be eliminated when a model is build to estimate $D_{\text {TDZ }}$ during trawl surveys. Only two factors (F1 and F2) used to check correlation between variable, because percentage of cumulative variance for combination F1F2 highest than F1-F3 and F2-F3 (Table 4).

Table 5. Correlation between variables and formed of common factors

\begin{tabular}{lcccccc}
\hline \multirow{2}{*}{ Variabels } & \multicolumn{3}{c}{ Component before rotation } & \multicolumn{3}{c}{ Component after rotation } \\
\cline { 2 - 7 } & F1 & F2 & F3 & F1 & F2 & F3 \\
\hline$|\mathrm{C}|$ & -0.79 & 0.36 & -0.03 & 0.86 & -0.01 & -0.08 \\
Speed & 0.28 & $\mathbf{0 . 5 2}$ & $-\mathbf{0 . 5 8}$ & $\mathbf{0 . 0 5}$ & $\mathbf{0 . 3 6}$ & 0.74 \\
Duration & -0.34 & $\mathbf{0 . 0 9}$ & 0.74 & 0.25 & 0.19 & -0.76 \\
Warp & $\mathbf{0 . 5 5}$ & $\mathbf{0 . 5 9}$ & 0.21 & -0.26 & 0.79 & 0.09 \\
Opening & 0.36 & 0.62 & 0.28 & -0.08 & 0.76 & -0.01 \\
Codend & -0.81 & 0.24 & -0.13 & 0.84 & -0.14 & -0.03 \\
Depth & 0.89 & -0.21 & 0.08 & -0.89 & 0.19 & 0.10 \\
\hline
\end{tabular}

Black bold: the absolute value $\geq 0.5$ of correlation between formed factors ( $F 1$ and $F 2$ ) and variables Red bold: the absolute value $<0.5$ of correlation between formed factors ( $F 1$ and $F 2$ ) and variables

Diagram of bi-plot correlation between component factor F1 and F2 for each variable (Figure 3), shows the influence of a component to bottom trawl according to its distance to axis of quadrant. The component of towing speed and towing duration has radians $<0.5$, these are not main components.

Decision of hypothesis-1 regarding significance of correlation between variables during trawling, $\mathrm{HO}$ was rejected, due to the occurence of significant correlation for several variables (i.e. $|\mathrm{C}|$, warp length, horizontal opening, biota non demersal at codend, and bottom depth). Meanwhile towing speed and towing duration have been not significant variable (Table 5 and Figure 2). Therefore, a new composition of variables was obtained that affected the trawl operation, which consisted of originally 7 variables to become 5 variables.

Otherwise being able to identify the main components, which contribute on trawl survey, the diagram PCA (Figure 3 ) indicates closeness or dependencies between components each other, according both of angle and direction neighborhood between components. Three groupings which have directly relationship each other were obtained. First group is i.e. warp length, horizontal openings, and towing speed. The second, is $|\mathrm{C}|$, biota non demersal at codend, and towing duration. Third, is bottom depth which is independent from the others variables.

\section{Principal Component of Trawl Dead Zone}

According to significance test (t-test) at 95\% confidence interval of four variables (i.e. bottom depth, warp length, trawl opening, and biota non demersal at cod end) to fish density on the pathway area $|C|$, that only warp length and bottom depth were significant, which t-test $>$ t-table (2.01) and $P$-value $<$ 0.05 . Meanwhile, density of biota non demersal at cod end, towing speed and towing duration were not significant (Table 6). 


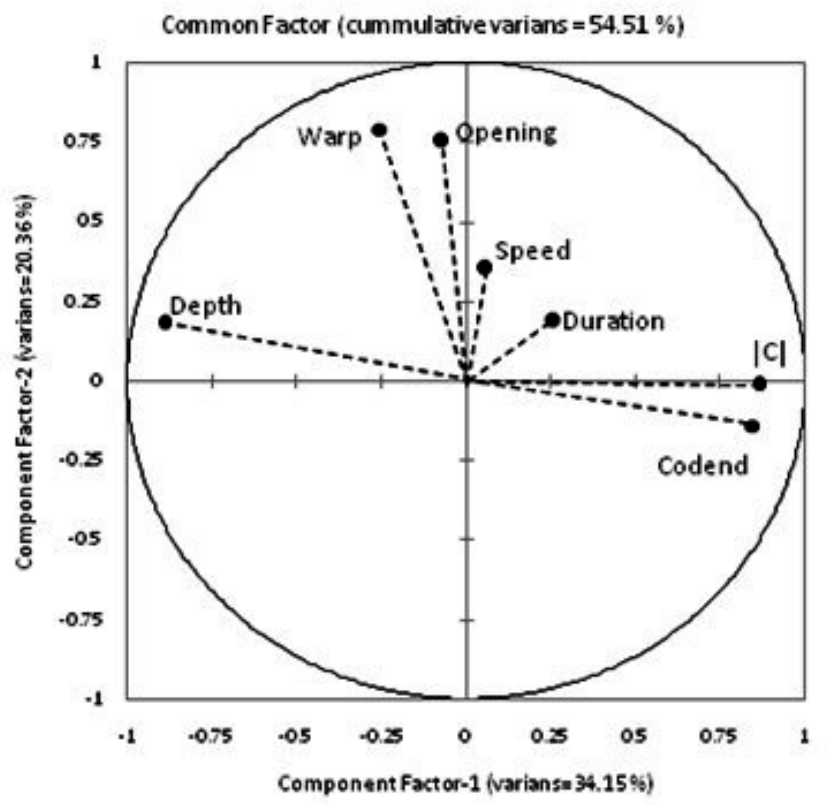

Figure 2. Correlation between components factor F1 and F2 for each trawling variable.

Table 6. Test of t-student for four variable were used on regression analysis

\begin{tabular}{lcccccc}
\hline \multirow{2}{*}{ Variables } & \multirow{2}{*}{ Coeficient } & Std. deviation & \multirow{2}{*}{} & \multirow{2}{*}{ Sig. } & \multicolumn{2}{c}{ Boundary } \\
\cline { 5 - 7 } & & & & & Upper & Lower \\
\hline Speed & 0.00 & 0.99 & 0.70 & 0.49 & -1.30 & 2.68 \\
Duration & 0.69 & 0.42 & $\mathbf{2 . 8 6}$ & $\mathbf{0 . 0 1}$ & 0.36 & 2.04 \\
Warp & 1.20 & 0.19 & 1.43 & 0.16 & -0.11 & 0.65 \\
Codend & 0.27 & 0.48 & $\mathbf{- 6 . 1 5}$ & $<\mathbf{0 . 0 0 1}$ & -3.94 & -2.00 \\
Depth & -2.97 & &
\end{tabular}

\section{Discussion}

\section{Fish Density on Trawl Dead Zone}

The acoustic fish density (DA) was higher than fish density from trawl (DT), that every fish on swept area was not to be able to catch during trawling. There was space occurring during trawling, which fish on it could not be caught due to some technical factors. The space is called the pathway area trawl (TDZ). There was high fish density which is not caught by trawler based and operating in Tarakan waters.

According to standard deviation for every survey period, each trawl station had various $D_{T D z}$. The trawling performance depend on sea conditions (physical oceanography), as well as demersal fish which have various abundance for each trawling station. Therefore, coefficient of catchability of bottom trawl will be varied according to spatial and temporal conditions.

The trawl net could be horizontal or vertical shift due to unstable tensile and resistance during towing. In addition, if warp length was too short while towing speed higher than certain speed limit, it will be lead trawl lifted up and not swept the bottom. Warp length was too long while towing speed below certain limit, trawl dredge the bottom.

Fish density on the pathway area can be measured by integrated acoustic and trawl survey. Fish density on the pathway area is comparing between fish density from acoustic and fish density by trawl. Fish on the pathway area is due to fish avoidance to trawl, and several technical error during trawling. In this study, estimation of fish density on the pathway area was measured from technical factors, while fish avoid the trawl is difficult to measure due to the not auxiliary equipment (i.e. underwater camera, current meter, CTD).

A local fish distribution could be interfered by various reactions of fish against the boat and trawl. Fish response to noise is possibility as a variable function of environment (Michalsen et al., 1996). It has long been recognized that fish can avoid to approaching vessels due to underwater noise considered the primary stimulus, that these behaviors can be as bias in fishery surveys. Reactions to approaching vessels are difficult variable to predict (De Robertis et al., 2012). 
In a bottom trawling, the process by which fish enter and are retained by a net involves a complex sequence of fish behaviors in response to the fishing vessel and the various components of trawl. The fish capture process begins well ahead of the vessel, where fish initially detect and respond to low frequency noise produced by the vessel, warps, doors, and trawl. The combination of these sounds produces an underwater-radiated noise signature that is highly specific to each vessel and trawling (Winger et al., 2010).

Noise vessel during towing can cause avoidance of fish reactions. However, propeller cavitation is the main source of noise which causes horizontal and vertical fish avoidance in front of the trawl. Fish avoidance will impact to trawl selectivity, especially when fish are mixed species and various length classes with differences of swimming capacity and behavior (Ona \& Godo, 1990).

\section{Principal Component on Trawl Survey}

The variables such as fish density on the pathway area, towing speed, towing duration, warp length, trawl door opening, density of biota non demersal fish in cod end, and bottom depth, are factors to contribute in capturing demersal fish, especially for trawler in Tarakan. There are interdependence between variables that will determine trawling successfully.

According to the series of components forming trawl system which base and operated in Tarakan waters, both of variable towing speed and towing duration are not major component regarding to the total catch. Changes in one or both these variables at a time, will not significantly affect regarding to catch rate. However, both variables were constant during towing. Speed was about 3 knots and 1 hour for towing duration for each trawl station.

Towing speed determined the success of the bottom trawling operation, if too fast, trawl mouth could be reversed or the net became floating. If too slow, trawl net could be sinking on the bottom, and ultimately will reduce net openings (Wudianto \& Barus, 1993). The effectiveness of bottom trawling achieved if swept on the right speed, therefore the trawl net establish a correct configuration at the bottom. Towing speed ranges between 3-5 knots (Anonymous, 1989). If towing very high speed, the swept area between otter board would be narrowed (Friedman, 1986).

Commonly, if towing duration is long times, it will increase catch until reaches the maximum capacity of cod end. However, it did not be occurring for trawlers operated in Tarakan waters. Demersal fish stock in Tarakan waters was lower abundance caused of over fishing (Mulyadi et al., 2005). However, the length of towing duration did not significantly affect to increase the catches.

There are three groups according the components that were correlated directly or dependent each other on a system of bottom trawls in Tarakan. First, is warp length, trawl door opening and towing speed.

The horizontal opening of trawl door was various for each station during survey, due to affected spread of otter board, determined by differences length and inclination of warp. Although, not only warp length and towing speed affected of trawl door spreading trawl door opening was varied depending on the weather, sea bed, sea current, and trawl design (Fridman, 1986). Direct observation by underwater camera or acoustic sounder net is required to determine the opening of trawl door properly.

The second group is fish density on the pathway area, density of biota non demersal in cod end, and towing duration. The pathway area is increasing, regarding to the longer of towing duration, due to increasing catch opportunity of density of biota non demersal (jellyfish, shellfish, etc.), that demersal fish could not be filled to the cod end. It possibility occurred due to the relatively lower abundance of demersal fish in Tarakan waters. The third group is bottom depth, which was independent variable from the other variable.

\section{Principal Component of The Pathway Area Of Trawl}

The trawler based and operated in Tarakan waters, has low catchability. That is one of the problems of demersal fish stock assessment. The catchability coefficient is proportional to demersal fish density on the pathway area, and could be measured through the integrated of acoustic-trawl survey.

Both variables of bottom depth and warp length were significantly affect to demersal fish density in the pathway area. Indeed, bottom depth is the main factor, which should be considered because of determination of the performance of bottom trawl and fishing capacity (Friedman, 1986).

Regarding to PCA, variables (i.e. bottom depth, warp length and trawl door opening) were in same quadrant. It proves a relationship between these variables. Bottom depth should be determined the warp length, not otherwise. Warp length determines the performance of otter board (Friedman, 1986). 
According to principal component analysis, the angle affect the distance between variable components of bottom depth and warp length indicated both variables to be low correlation. It means that for each trawling station, warp length was not adjusted according to changing of bottom depth. Indeed, when bottom depth increased during towing, warp length should be increased and vice versa. Therefore, the high density of demersal fish was occurring on the pathway area during surveys.

\section{CONCLUSION}

Two variables (i.e. warp length and bottom depth) as principal components were affected the fish density at the pathway area for bottom trawlers based and operated in Tarakan waters. Four variables (i.e. towing speed, towing duration, trawl door opening and abundance of biota non demersal at cod end were not principal components.

Acoustic system has dead zones, it is zone which could not be covered with acoustic beam transmitted. In the future, "the trawl blank zone" can be allowed as the pathway area on trawl operations. That is enable to estimate the optimum ratio between warp length and bottom depth. It could be derived according to lower fish density at the pathway area (blank zone of trawl).

\section{ACKNOWLEDGEMENTS}

The authors wish to thank The Stock Assessment for Demersal Fish Project in 2012 has funded the research. We also would like to thank to some researchers at the Research Institute for Marine Fisheries section of demersal fish for their invaluable suggestions to this paper.

\section{REFERENCES}

Anonymous. (1989). Transcript of Lectures Trawling Gear Methods. (p. 91). OFCF. Tokyo.

De Robertis, A. \& Handegard, N.O. (2012). Fish Avoidance Of Research Vessels And The Efficacy Of Noise-Reduced Vessels: A Review. ICES Journal of Marine Science. doi:10.1093/icesjms/fss 155.

Friedman, A. I. (1986). Calculation for Fishing Gear Design (p. 153-189). Translated From Russian By PJG. Carothers. FAO, Rome.

Grosslein, M. D. \& Laurec, A. (1982). Bottom Trawl Surveis: Design, Operation and Analysis (p. 25p). CECAF/ECAF Series/81/22 (En). FAO. Rome.
Hair, J. F., Tatham, R. L., Anderson R. E. \& Black, W. (1998). Multivariate data analysis. 5th Ed. Prentice-Hall: London.

MacLennan, D. N. \& Simmonds, E. J. (2005). Fisheries Acoustics (p. 326). London. Chapman \& Hall.

Mello, L. G. S. \& Rose, G. A. (2009). The Acoustic Dead Zone: Theoretical Vs Empirical Estimates, And Its Effect On Density Measurements Of SemiDemersal Fish. ICES Journal of Marine Science. 66, 1364-1369.

Michalsen, K., Godø, O. R. \& Freon, A. (1996). Diel Variation in the Catchability of Gadoids and Its Influence on Reliability of Abundance Estimates. ICES J. Mar. Sci. 53, 389-395.

Mulyadi, E., Saptoyo, Nuryadi \& Tofani, A. (2005). (in Indonesian). Identification of Demersal fish resource in East of Kalimantan Boundary Waters. Internal Technical Report. BPPI Semarang.

Ona, E. \& Godo, O. R. (1990). Fish Reaction to Trawling Noise: The Significance for Trawl Sampling. Rapp. P.v. Riun. Cons. int. Explor. Mer. 189, 159-166.

Ona, E. \& Mitson, R. B. (1996). Acoustic Sampling And Signal Processing Near The Seabed: The Dead Zone Revisited. ICES Journal of Marine Science. 53, 677-690.

Pauly, D., Martosubroto, P. \& Saeger, J. (1996). The Mutiara 4 Surveys in the Java and South China Seas, November 1974 to July 1976 (pp. 47-54). In Pauly D, Martosubroto P, editor. Translated from The Fish Resources of Western Indonesia. DGFT2-ICLARM.

Priatna, A., Purbayanto, A., Simbolon, D. \& Hestirianoto, T. (2014). (In Indonesian). The Catchability of Bottom Trawl to Demersal Fish in Tarakan Waters. J. Lit. Perikan. Ind. 20(1), 1930.

RIMF. (2012). (In Indonesian). Demersal fish stock assessment in Sulawesi Sea and Java Sea ( $p$. 288). Jakarta: Research Institute for Marine Fisheries. Final Project Report.

Tampubolon, G. P, \& Monintja, D. R. (1995). (In Indonesian). Stok Estimation of Demersal Fish by Swept Area Method (p. 12). Cruise Sandipati Bahari. 
Von Szalay, P.G, Somerton, D.A. \& Kotwicki, S. (2007). Correlating trawl and acoustic data in the eastern Bering Sea: A first step toward improving biomass estimates of walleye pollock (Theragra chalcogramma) and Pacific cod (Gadus macrocephalus). Fisheries Research. 86:77-83.

Wallace, J. R. \& West, C. W. (2006). Measurements of Distance Fished During the Trawl Retrieval Period. Fisheries Research. 77, 285-292.

Walsh, S. J. (1996). Efficiency of Bottom Sampling Trawls in Deriving Survei Abundance Indices. NAFO Science Council Studies. 28, 9-24.
Winger, P. D., Eayrs, S., \& Glass, C. W. (2010). Fish Behavior near Bottom Trawls (Chapter 4) (p. 67104). Part Two: Fish Behavior near Fishing Gears during Capture Processes. Behavior of Marine Fishes Capture Processes and Conservation Challenges. Blackwell Publishing Ltd.

Wudianto \& Barus, H. R. (1993). (In Indonesian). Fishing of The Deep Sea Shrimp by Beam Trawl. J. Lit. Perikan Laut. 77, 92-106. 